\title{
GAMBARAN INTENSITAS PENCAHAYAAN DAN KELELAHAN MATA PADA SISWA SDN PAGADEAN SUBANG TAHUN 2017
}

\author{
Arief Witjaksono $^{1}$, Winda Kurniasari ${ }^{2}$ \\ Awicaks07@yahoo.co.id \\ Program Studi D3 Refraksi optisi STIKes Dharma Husada Bandung
}

Pemakaian fasilitas kerja yang tidak ergonomis akan menyebabkan perasaan tidak nyaman, konsentrasi menurun, mengantuk dan lain sebagainya, hal ini dapat terjadi pada siswa sekolah dasar dalam kualitas penerangan ruang kelas. Adapun bila kondisi tersebut berlangsung lama dan secara terus menerus selama masa sekolah akibat yang di timbulkan akan lebih jauh dapat menyebabkan gangguan penglihatan. Tujuan penelitian ini mengetahui gambaran intensitas pencahayaan dan kelelahan mata pada siswa SDN Pagadean Subang. Jenis penelitian ini observasional yang bersifat deskriptif kuantitatif, yaitu data yang diperoleh dari sampel populasi penelitian dianalisis sesuai dengan metode statistik yang digunakan. Penelitian deskriptif di maksudkan untuk mendapatkan gambaran mengenai intensitas pencahayaan dan kelelahan mata. Populasi penelitian ini adalah siswa kelas I dan V di SDN Pagadean Subang yang berjumlah 64 orang dan semua dijadikan sampel jenuh. Hasil penelitian menunjukan intensitas pencahayaan ruang kelas 1 dan ruang kelas $\mathrm{V}$ dibawah standar SNI dan terdapat 9 siswa (14.1\%) mengalami kelelahan mata. Penyelenggara pendidikan diharapkan untuk meningkatkan intensitas pencahayaan didalam ruang kelas I dan V agar sesuai dengan standar intensitas pencahayaan menurut SNI 03-6197-2000 tahun 2011 sebesar 300 lux.

Kata Kunci : Intensitas Pencahayaan, Kelelahan Mata, Siswa SD

\section{PENDAHULUAN}

Pendidikan merupakan kegiatan yang sangat penting untuk perkembangan, terutama pendidikan dasar karena pada jenjang pendidikan dasar peserta didik akan dibentuk karakter agar bisa lebih baik di masa mendatang, dengan adanya pendidikan dapat meningkatkan pola pikir seorang manusia hingga kedepannya bisa membentuk pribadi yang lebih baik.

Sekolah Dasar dapat dikatakan sebagai kegiatan yang mendasari tiga aspek, yaitu pengetahuan, sikap, dan keterampilan. Ruang kelas umumnya merupakan suatu ruangan yang berfungsi sebagai tempat untuk kegiatan tatap muka dalam proses kegiatan belajar mengajar.
Kondisi yang nyaman dan sehat adalah salah satu faktor yang sangat penting dalam menunjang proses belajar dan mengajar yang berlangsung. Menurut Permendiknas (2007) mengatakan bahwa “....kelas tidak hanya harus nyaman tetapi juga harus memenuhi standar yang di tetapkan yang berkorelasi dengan kesehatan dari peserta didik dan juga para guru. Rasio minumun ruang kelas di sekolah dasar adalah $2 \mathrm{~m}^{2} /$ peserta didik, dengan luas minimum ruang kelas adalah $30 \mathrm{~m}^{2}$, dimana lebar minimunya adalah 5 $\mathrm{m}^{2}$. Suatu ruang kelas di haruskan untuk memiliki jendela yang memungkinkan pencahayaan yang memadai untuk 
membaca buku dan untuk memberikan pandangan ke luar ruangan”.

Ergonomi adalah suatu ilmu yang mempelajari tentang hubungan kenyamanan dan efektivitas sebuah alat kerja dengan manusia sebagai pemakainya. Dengan penerapan ergonomi maka akan tercipta lingkungan yang aman, sehat, dan nyaman sehingga kegiatan menjadi lebih produktif dan efesien.

Pencahayaan merupakan sumber terbaik bagi bangunan, tidak terkecuali untuk bangunan sekolah. Intensitas pencahayaan yang baik akan berdampak pada kenyamanan proses belajar mengajar di ruang kelas. Hasil penelitian Irnawaty (2016) menyatakan bahwa "Sebagian besar intensitas pencahayaan ruang kelas Sekolah Dasar di Kota Makassar berada dibawah standar pencahayaan rata-rata SNI ruang kelas. Sebanyak $87,9 \%$ dibawah nilai standar pencahayaan rata-rata SNI untuk ruang kelas dan hanya sebanyak $12,1 \%$ yang diatas nilai standar SNI".

Usia 5-12 tahun merupakan usia perkembangan anak sekolah dimana pada usia ini terjadi perubahan-perubahan pada diri anak seperti perubahan pada aspek fisik, kognitif, emosi dan psikisional. Desain penerangan diruang kelas seharusnya di sesuaikan dengan keadaan bangunan dan tata letaknya. Secara umum di Indonesia belum dilakukan analisa fenomena dasar penerangan untuk fasilitas belajar di Sekolah Dasar, sehingga murid sekolah juga mempunyai peluang untuk menderita kelelahan mata dan dapat mengganggu kesehatan terutama kesehatan penglihatan siswa Sekolah Dasar. Berdasarkan survei pendahuluan yang telah dilakukan pada tanggal 2 Maret 2018 di SDN Pagadean diketahui bahwa kondisi penerangan di ruang kelas I dan V kurang terang dengan menggunakan penerangan buatan (lampu), jumlah lampu yang digunakan hanya ada satu lampu. Intensitas penerangannya tidak merata, secara teori kondisi ini dapat menyebabkan kelelahan mata pada siswa SDN Pagadean Subang.

Tujuan penelitian untuk mengetahui gambaran intensitas pencahayaan dan kelelahan mata pada siswa SDN Pagadean Subang.

\section{METODOLOGI PENELITIAN}

Kerangka konsep pada penelitian ini dibatasi intensitas pencahayaan dan kelelahan mata. Variabel penelitian berdasarkan kerangka konsep penelitian adalah intensitas pencahayaan ruang kelas dan kelelahan mata pada siswa di SDN Pagadean Subang.

Penelitian ini termasuk kedalam jenis penelitian Observasional yang bersifat deskriptif kuantitatif, yaitu data yang 
diperoleh dari sampel populasi penelitian di analisis sesuai dengan metode statistik yang digunakan. Penelitian deskriptif dalam penelitian ini di maksudkan untuk mendapatkan gambaran dan keteranganketerangan mengenai intensitas pencahayaan dan kelelahan mata pada siswa di SDN Pagadean Subang.

Pendekatan waktu pengumpulan data yang digunakan dalam penelitian ini adalah Cross Sectional yaitu dimana metode dengan cara pendekatan, observasi atau pengumpulan data sekaligus pada suatu saat (point time approach) yang artinya dimana subjek penelitian hanya diobservasi sekali saja (Notoatmodjo, 2012).

Populasi penelitian ini dibatasi yaitu pada siswa kelas I dan V di SDN Pagadean Subang yang berjumlah 64 orang.

Dalam penelitian ini sampel yang diteliti adalah siswa kelas I dan V di SDN Pagadean Subang sebanyak 64 orang yang diambil secara total sampling yaitu, menjadikan seluruh populasi yang ada untuk menjadi sampel dalam penelitian ini. (Sugiyono, 2013)

Instrument yang digunakan dalam penelitian berupa alat ukur intensitas pencahayaan yaitu lux meter yang digunakan untuk mengukur pencahayaan di ruang kelas dan kuesioner yang berisikan item pertanyaan mengenai kelelahan mata.

Pada penelitian ini dilakukan uji konten atau validitas isi artinya peneliti menanyakan langsung kepada pakar terkait item pertanyaan mengenai gejala kelelahan mata yaitu kepada dua pakar ahli. Dalam penelitian ini uji konten dilakukan terhadap dua ahli dalam bidangnya.

Cara pengambilan data dilakukan dengan cara mengukur intensitas pencahayaan di ruang kelas SDN Pagadean Subang dengan menggunakan alat ukur berupa lux meter. Pengumpulan data dilakukan dengan cara membagikan lembar kuesioner pada responden

Analisa data yang digunakan dalam penelitian ini yaitu menggunakan analisa univariat, untuk memperoleh gambaran distribusi frekuensi dari variabel yang diteliti. Variabel yang di deskripsikan adalah intensitas penyacahayaan terhadap kelelahan mata dengan intensitas pencahayaan sebelum dan sesudah dilakukan pengukuran.

Rumus distribusi frekuensi adalah sebagai berikut :

$\mathrm{P}=\frac{f}{N} 100 \%$

Keterangan :

P : Presentase untuk setiap kategori

f : Jumlah setiap kategori

$\mathrm{N}$ : Jumlah total responden 
HASIL

Tabel 1

Karakteristik Responden Berdasarkan

Usia Pada Siswa Kelas I dan V SDN Pagadean Subang Tahun 2017

\begin{tabular}{cccc}
\hline No & Usia & Jumlah & Persentase \\
\hline 1 & 10 Tahun & 18 & $28.1 \%$ \\
2 & 11 Tahun & 8 & $12.5 \%$ \\
3 & 12 Tahun & 4 & $6.3 \%$ \\
4 & 6 Tahun & 2 & $3.1 \%$ \\
5 & 7 Tahun & 26 & $40.7 \%$ \\
6 & 8 Tahun & 3 & $4.7 \%$ \\
7 & 9 Tahun & 3 & $4.7 \%$ \\
\hline & Total & $\mathbf{6 4}$ & $\mathbf{1 0 0 . 0 \%}$ \\
\hline
\end{tabular}

Sumber : Hasil penelitian

Tabel 1 menjelaskan bahwa karakteristik responden, paling banyak adalah berusia 7 tahun berjumlah 26 responden (40.6\%).
Tabel 2

Karakteristik Responden Berdasarkan Jenis Kelamin Pada Siswa Kelas I dan V SDN Pagadean Subang Tahun 2017

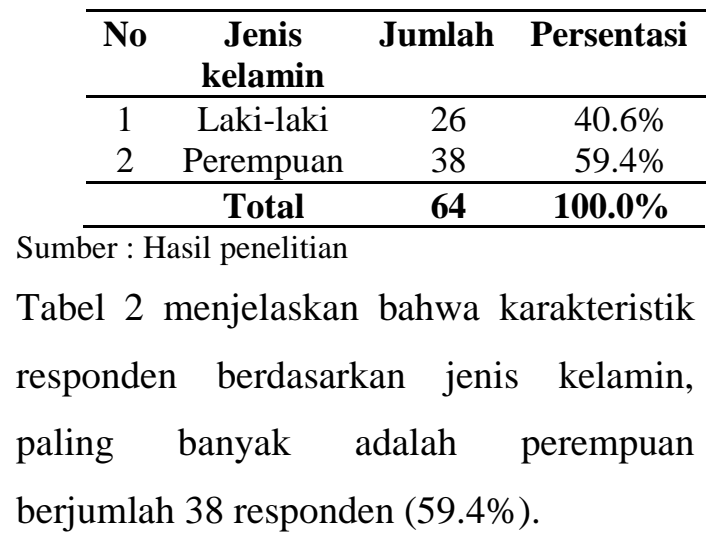

Tabel 3

Hasil Pengukuran Intensitas Pencahayaan Ruang Kelas I di SDN Pagadean Subang Tahun 2017

\begin{tabular}{cccc}
\hline Kondisi pengukuran & \multicolumn{2}{c}{ Rata-rata Tingkat Pencahayaan } & \multirow{2}{*}{$\begin{array}{c}\text { Total Rata- } \\
\text { rata }\end{array}$} \\
\cline { 2 - 3 } & Lantai & Dinding & $20.27087 \mathrm{lux}$ \\
Tanpa penerangan & $16.60 \mathrm{lux}$ & $23.94 \mathrm{lux}$ & \\
Dengan penerangan & $22.38 \mathrm{lux}$ & $33.62 \mathrm{lux}$ & $27.99842 \mathrm{lux}$ \\
\hline
\end{tabular}

Sumber : Hasil Penelitian

Dari tabel 3, nilai rata-rata intensitas pencahayaan ruang kelas I tanpa penerangan buatan (lampu) yaitu 20.27087

lux. Intensitas pencahayaan rata-rata dengan menggunakan penerangan buatan (lampu) yaitu 27.99842 lux. Intensitas pencahayaan tersebut tidak memenuhi standar, karena menurut SNI 03-61972000 tahun 2011, standar intensitas pencahayaan ruang kelas sebesar 300 lux.

Tabel 4

Selisih Intensitas Pencahayaan Dengan Penerangan dan Tanpa Penerangan Ruang Kelas I di SDN Pagadean Subang

Tahun 2017

\begin{tabular}{cccc}
\hline \multirow{2}{*}{ Pengukuran } & \multicolumn{2}{c}{ Kategori Rata-rata Intensitas Pencahayaan } & \multirow{2}{*}{ Selisih } \\
\cline { 2 - 3 } & Dengan penerangan & Tanpa Penerangan & \\
\hline Lantai & $22.38 \mathrm{lux}$ & $16.60 \mathrm{lux}$ & $5.78 \mathrm{lux}$ \\
Dinding & $33.62 \mathrm{lux}$ & $22.38 \mathrm{lux}$ & $11.24 \mathrm{lux}$ \\
\hline Sumber : Hasil Penelitian & & &
\end{tabular}


Hasil pengukuran intensitas pencahayaan lantai dengan penerangan : 22.38 lux tanpa penerangan : 16.60 lux, maka selisihnya : 5.78 lux. Pengukuran intensitas pencahayaan dinding dengan penerangan : 33.62 lux tanpa penerangan : 22.38 lux, maka selisihnya : 11.24 lux.

Dalam ruang kelas I ada dua titik lampu, jumlah lampu dalam satu titik ada satu lampu. Panjang ruangan 7 meter, lebar 6 meter. Target kuat penerangan yang harus ada didalam ruang kelas adalah 300 lux. LLF (Light Loss Factor) atau bisa di sebut faktor cahaya rugi yang dihasilkan dalam sebuah ruangan nilainya sebesar 0.7 sampai 0.8, sedangkan CU (Coeffesien of Utilization) atau faktor pemanfaatannya sebesar $0.48 \%$, dapat diketahui pada lampu 1 lumen nilainya sama dengan 75 watt.

Berikut perhitungannya :

$$
\begin{array}{ll}
\mathrm{N} & =2 \text { Titik lampu didalam ruangan } \\
\epsilon & =300 \mathrm{Lux} \\
\mathrm{L} & =7 \\
\mathrm{~W} & =6 \\
\mathrm{LLF} & =0.7-0,8 \\
\mathrm{Cu} & =48 \%(0,48) \\
1 \text { lumen } \quad=75 \text { watt } \\
\mathrm{N} \quad=1 \text { Lampu pada titik }
\end{array}
$$

Ditanyakan : Total nilai pencahayaan $(\varnothing)$ ?

$$
\begin{array}{r}
\emptyset=\frac{\in \times L \times W}{L L F \times C u \times n \times N} \\
\emptyset=\frac{300 \times 7 \times 6}{0,8 \times 0,48 \times 1 \times 2} \\
\emptyset=\frac{12600}{0,768} \\
\emptyset=16406 \text { lumen }=\frac{16406}{75}=218 \mathrm{Watt}
\end{array}
$$

Lampu yang dibutuhkan dalam ruang kelas I untuk memenuhi standar yang telah di tetapkan adalah 16406 lumen atau 218 watt dengan menggunakan lampu TL (Tubular Lamp) atau lampu tabung. Menurut E-Journal Teknik Elektro tahun 2015, jumlah lampu pada suatu ruangan:

$$
\mathrm{N}=\frac{E \times A}{\Phi l a m p u \times L L F \times C u}
$$

Dimana :

$$
\begin{aligned}
& \text { Фlampu = I } \times \mathrm{P} \\
& N \quad=\text { Jumlah titik lampu } \\
& E \quad \text { = Target kuat penerangan yang } \\
& \text { akan dicapai (Lux) } \\
& \Phi \quad=\text { Flux cahaya (Lumen) } \\
& L L F \quad=0.8 \\
& \mathrm{P} \quad=\text { Daya (Watt) } \\
& \mathrm{I} \quad=75 \text { Lumen } \\
& \mathrm{A} \quad=\text { Luas ruangan (meter) }
\end{aligned}
$$

Perhitungan untuk menentukan jumlah titik lampu didalam ruang kelas I untuk mencapai 218 watt dengan menggunakan lampu TL (Tubular Lamp), maka kebutuhan jumlah lampu adalah sebagai berikut :

Tahap pertama dilakukaen perhitungan luas ruangan, yaitu :

$$
\begin{aligned}
A \quad & =\mathrm{P} \times \mathrm{L} \\
& =7 \times 6 \\
& =42 \mathrm{~m}^{2}
\end{aligned}
$$

Tahap kedua perhitungan flux cahaya lampu (lumen), yaitu :

Фlampu $=\mathrm{I} \times \mathrm{P}$

$=75 \times 140 \mathrm{watt}$

$=10500$ lumen 
Maka jumlah lampu yang dibutuhkan adalah :

$$
\begin{aligned}
\mathrm{N} & =\frac{E \times A}{\Phi \text { lampu } \times L L F \times C u} \\
\mathrm{~N} & =\frac{300 \times 42}{10500 \times 0,8 \times 0,48} \\
\mathrm{~N} & =\frac{17.600}{4032}=3.1
\end{aligned}
$$

Berdasarkan hasil perhitungan tersebut untuk jumlah lampu yang dibutuhkan dalam ruang kelas I sebanyak 3 lampu TL (Tubular Lamp).

Tabel 5

Hasil Pengukuran Intensitas Pencahayaan Ruang Kelas V di SDN Pagadean Subang Tahun 2017

\begin{tabular}{cccc}
\hline Kondisi pengukuran & \multicolumn{2}{c}{ Rata-rata Tingkat Pencahayaan } & \multirow{2}{*}{$\begin{array}{c}\text { Total Rata- } \\
\text { rata }\end{array}$} \\
\cline { 2 - 3 } & Lantai & Dinding & \\
\hline Tanpa penerangan & $69.20 \mathrm{lux}$ & $60.80 \mathrm{lux}$ & 65.00034 lux \\
Dengan penerangan & $80.80 \mathrm{lux}$ & $67.89 \mathrm{lux}$ & $74.34536 \mathrm{lux}$ \\
\hline Sumber : Hasil Penelitian & & &
\end{tabular}

Dari tabel 5 nilai rata-rata intensitas tersebut tidak memenuhi standar, karena pencahayaan tanpa penerangan buatan menurut SNI 03-6197-2000 tahun 2011 (lampu) yaitu 65.00034 lux. Sedangkan intensitas pencahayaan rata-rata dengan menggunakan penerangan buatan (lampu) seharusya untuk standar pencahayaan ruang kelas memiliki intensitas yaitu 74.34536 lux. Intensitas pencahayaan pencahayaan sebesar 300 lux.

Tabel 6

Selisih Intensitas Pencahayaan Dengan Penerangan dan Tanpa Penerangan Ruang Kelas V di SDN Pagadean Subang

Tahun 2017

\begin{tabular}{cccc}
\hline \multirow{2}{*}{ Pengukuran } & \multicolumn{2}{c}{ Kategori Rata-rata Intensitas Pencahayaan } & \multirow{2}{*}{ Selisih } \\
\cline { 2 - 3 } & Dengan penerangan & Tanpa Penerangan & \\
\hline Lantai & $80.80 \mathrm{lux}$ & $69.20 \mathrm{lux}$ & $11.6 \mathrm{lux}$ \\
Dinding & $67.89 \mathrm{lux}$ & $60.80 \mathrm{lux}$ & $7.09 \mathrm{lux}$ \\
\hline Sumber : Hasil Penelitian & &
\end{tabular}

Dari tabel 6 intensitas pencahayaan lantai dengan penerangan adalah 80.80 lux sedangkan tanpa penerangan adalah 69.20 lux maka selisihnya adalah 11.6 lux.
Pengukuran intensitas pencahayaan dinding dengan penerangan : 67.89 lux sedangkan tanpa penerangan : 60.80 lux, selisihnya : 7.09 lux. 
Didalam ruang kelas $\mathrm{V}$ ada dua titik lampu, jumlah lampu dalam satu titik ada satu lampu. Panjang ruangan 7 meter, lebar ruangan 5 meter. Target kuat penerangan yang harus ada didalam ruang kelas adalah 300 lux. LLF (Light Loss Factor) atau bisa di sebut faktor cahaya rugi yang dihasilkan dalam sebuah ruangan nilainya sebesar 0.7 sampai 0.8, sedangkan CU (Coeffesien Of Utilization) atau faktor pemanfaatannya sebesar 0.64. Diketahui pada lampu 1 lumen nilainya sama dengan 75 watt, maka lampu yang harus di butuhkan dalam ruang kelas I ini untuk memenuhi standar yang telah di tetapkan adalah 7812.5 lumen atau 104.1667 watt.

Berikut perhitungannya :

$\mathrm{N}=2$ Titik lampu didalam ruangan $\epsilon=300$ Lux

$\mathrm{L}=7$

$\mathrm{W}=5$

$\mathrm{LLF}=0.7-0,8$

$\mathrm{Cu}=64 \%(0,64)$

1 lumen $=75$ watt

$\mathrm{n}=1$ Lampu pada titik

Ditanyakan : Total nilai pencahayaan $(\varnothing)$ ?

$$
\begin{gathered}
\emptyset=\frac{\epsilon \times L \times W}{L L F \times C u \times n \times N} \\
\emptyset=\frac{300 \times 7 \times 5}{0,8 \times 0,64 \times 1 \times 2} \\
\emptyset=\frac{10500}{1,024} \\
\emptyset=1025 \text { lumen }=\frac{10253}{75}=140 \mathrm{Watt} \\
\text { Berdasarkan hasil perhitungan, lampu } \\
\text { yang di butuhkan dalam ruang kelas V } \\
\text { untuk memenuhi standar adalah 1025 } \\
\text { lumen atau 140 watt dengan menggunakan }
\end{gathered}
$$

lampu TL (Tubular Lamp) atau lampu tabung. Menurut E-Journal Teknik Elektro tahun 2015, untuk mendapatkan jumlah lampu pada suatu ruagan dapat di hitung dengan rumus sebagai berikut :

$$
\begin{aligned}
& \mathrm{N}= \\
& \frac{E \times A}{\Phi l a m p u \times L L F \times C u} \\
& \text { Dimana : } \\
& \Phi \text { lampu }=\mathrm{I} \times \mathrm{P} \\
& N=\text { Jumlah titik } \\
& \text { lampu } \\
& E=\text { Target kuat } \\
& \text { penerangan yang akan } \\
& \text { dicapai (Lux) } \\
& \Phi=\text { Flux cahaya } \\
& \text { (Lumen) } \\
& L L F \quad=0.8 \\
& \mathrm{P} \quad=\text { Daya (Watt) } \\
& \text { I } \quad=75 \text { Lumen } \\
& \mathrm{A}=\text { Luas ruangan } \\
& \text { (meter) }
\end{aligned}
$$

Perhitungan untuk menentukan jumlah titik lampu didalam ruang kelas I untuk mencapai 136 watt dengan menggunakan lampu TL (Tubular Lamp) adalah sebagai berikut :

Tahap pertama dilakukan perhitungan luas ruangan, yaitu :

$$
\begin{aligned}
A \quad & =\mathrm{P} \times \mathrm{L} \\
& =7 \times 5 \\
& =35 \mathrm{~m}^{2}
\end{aligned}
$$

Tahap kedua perhitungan flux cahaya lampu (lumen), yaitu :

$$
\begin{aligned}
\text { Ilampu } & =\mathrm{I} \times \mathrm{P} \\
& =75 \times 140 \text { watt } \\
& =10500 \text { lumen }
\end{aligned}
$$

Maka jumlah lampu yang dibutuhkan adalah :

$$
\mathrm{N}=\frac{E \times A}{\text { Фlampu } \times L L F \times C u}
$$




$$
\begin{aligned}
& \mathrm{N}=\frac{300 \times 35}{10500 \times 0,8 \times 0,64} \\
& \mathrm{~N}=\frac{10500}{5376}=2
\end{aligned}
$$

Berdasarkan hasil perhitungan, jumlah lampu yang dibutuhkan dalam ruang kelas V sebanyak 2 lampu TL (Tubular Lamp).

Tabel 7

Distribusi Frekuensi Kejadian Kelelahan Mata pada Siswa Kelas I dan V di SDN Pagadean Subang Tahun 2017

\begin{tabular}{cccc}
\hline No & Kejadian kelelahan mata & Jumlah & Presentase \\
\hline 1 & Mengalami & 9 & $14.1 \%$ \\
2 & Tidak mengalami & 55 & $85.9 \%$ \\
\hline & Total & $\mathbf{6 4}$ & $\mathbf{1 0 0 \%}$ \\
\hline
\end{tabular}

Sumber : Hasil Penelitian

Dari tabel 7 tersebut, menunjukan bahwa

dari 64 siswa yang menjadi responden dalam penelitian ini sejumlah 9 orang
(14.1\%) mengalami kelelahan mata dan 55 orang $(85.9 \%)$ tidak mengalami kelelahan mata.

Tabel 8

\section{Distribusi Frekuensi Keluhan kelelahan mata pada siswa kelas I dan V di SDN Pagadean Subang Tahun 2017}

\begin{tabular}{llccccc}
\hline \multirow{2}{*}{ No } & \multicolumn{2}{c}{ Keluhan } & \multicolumn{2}{c}{ Mengalami } & \multicolumn{2}{c}{ Tidak } \\
& & \multicolumn{3}{c}{ Mengalami } & \multirow{2}{*}{ Total } \\
\cline { 3 - 5 } & & $\mathrm{N}$ & $\%$ & $\mathrm{~N}$ & $\%$ & \\
\hline 1 & Mata Terasa Berat & 34 & $53.1 \%$ & 30 & $46.9 \%$ & 64 \\
2 & Mata Terasa Panas & 4 & $6.3 \%$ & 60 & $93.8 \%$ & 64 \\
3 & Sakit disekitar mata & 11 & $17.2 \%$ & 53 & $82.8 \%$ & 64 \\
4 & Penglihatan menjadi kabur & 7 & $10.9 \%$ & 57 & $89.1 \%$ & 64 \\
5 & Penglihatan berbayang & 9 & $14.1 \%$ & 55 & $85.9 \%$ & 64 \\
6 & Penglihatan sulit difokuskan & 26 & $40.6 \%$ & 38 & $59.4 \%$ & 64 \\
7 & Bahu terasa nyeri & 15 & $23.4 \%$ & 49 & $76.6 \%$ & 64 \\
8 & Leher terasa nyeri & 17 & $26.6 \%$ & 47 & $73.4 \%$ & 64 \\
9 & Sakit kepala & 28 & $43.8 \%$ & 36 & $56.3 \%$ & 64 \\
\hline \multicolumn{2}{l}{ Sumber : Hasil Penelitian } & & & & &
\end{tabular}

Tabel 8 menunjukan bahwa distribusi keluhan kelelahan mata pada siswa kelas I dan $\mathrm{V}$ dari 64 responden keluhan yang paling banyak di alami adalah mata terasa berat berjumlah 34 responden $(53.1 \%)$, sedangkan keluhan yang paling sedikit di alami oleh responden adalah mata terasa panas berjumlah 4 responden $(6.3 \%)$. 


\section{PEMBAHASAN}

\section{Gambaran Intensitas Pencahayaan Ruang Kelas I dan V di SDN Pagadean Subang Tahun 2017}

Gambaran hasil pengukuran intensitas pencahayaann ruang kelas I dengan kondisi pengukuran saat lampu dimatikan memiliki intensitas pencahayaan 16.18429 lux, sedangkan kondisi pengukuran saat lampu di nyalakan memiliki intensitas pencahayaan 22.86592 lux. Ruang kelas $\mathrm{V}$ dengan kondisi pengukuran saat lampu di matikan memiliki intensitas pencahayaan 53.5125 lux, sedangkan kondisi pengukuran saat lampu di nyalakan memiliki intensitas pencahayaan 62.5525 lux. Menurut SNI 03-6197-2000 tahun 2011 seharusya untuk standar pencahayaan ruang kelas memiliki intensitas pencahayaan sebesar 300 lux, ruang kelas I dan kelas $\mathrm{V}$ menunjukan bahwa intensitas pencahayaan kedua ruangan tersebut tidak memenuhi standar SNI 03-61972000 tahun 2011. Hal ini disebabkan karena beberapa fakor yaitu, terdapat salah satu lampu yang tidak menyala, sumber cahaya alami yang seharusnya masuk melalui jendela terhalang oleh kelas lain, keadaan ruangan yang kurang bersih, karena kebersihan ruangan mempengaruhi intensitas pencahayaan. Sesuai dengan penelitian
Nursalin, semakin kotor ruangan maka kualitas pencahayaan akan semakin menurun, dan semakin bersih ruangan maka kualitas pencahayaan akan semakin baik.

Penelitian ini sejalan dengan Irnawaty yang melakukan penelitian mengenai intensitas pencahayaan ruang kelas sekoah dasar di Makassar pada tahun 2016, menunjukan bahwa sebagian besar intensitas pencahayaan ruang kelas Sekolah Dasar di Kota Makassar berada dibawah standar pencahayaan rata-rata SNI ruang kelas. Sebanyak $87,9 \%$ dibawah nilai standar pencahayaan rata-rata SNI untuk ruang kelas dan hanya sebanyak $12,1 \%$ yang diatas nilai standar SNI.

Menurut Darma setiawan dan Puspa kesuma (1991:20), lampu yang dipakai dalam ruang kelas sebaiknya lampu dengan warna cahaya putih netral yang cahayanya dapat menyatu dengan baik dengan cahaya alami. Jenis lampu yang disarankan untuk ruang kelas dengan tinggi sampai dengan 3 meter adalah lampu TL (Tubular Lamp) atau lampu neon. Maka untuk ruang kelas I diperlukan 3 titik lampu TL (Tubular Lamp) dengan kapasitas 140 watt dan untuk ruang kelas $\mathrm{V}$ diperlukan 2 titik lampu TL (Tubular Lamp) dengan kapasitas 140 watt. 
2. Gambaran Kelelahan Mata Pada Siswa Kelas I dan V di SDN Pagadean Subang Tahun 2017

Karakteristik responden mempengaruhi kelelahan mata, di antaranya adalah usia. Pada usia anak, akomodasi mata sangat kuat maka dalam kondisi pencahayaan yang redup anak berusaha untuk melihat dengan detail, dalam kondisi tersebut akan menyebabkan kelelahan mata (Guyton, 1991).

Kelelahan mata pada siswa kelas I dan V di SDN Pagadean Subang tahun 2018 dari 64 responden, 9 orang $(14.1 \%)$ di antaranya mengalami kelelahan mata dan 55 orang $(85.9 \%)$ tidak mengalami kelelahan mata. Gejala-gejala kelelahan mata antara lain mata terasa berat, mata terasa panas, sakit disekitar mata, penglihatan menjadi kabur, penglihatan berbayang, penglihatan sulit difokuskan, bahu terasa nyeri, leher terasa nyeri, dan sakit kepala. Hasil penelitian tentang keluhan kelelahan mata pada siswa kelas 1 dan $\mathrm{V}$ tertinggi diantaranya keluhan mata terasa berat sebanyak 34 responden $(53.1 \%)$, keluhan sakit kepala sebanyak 28 responden (43.8\%), dan keluhan penglihatan sulit di fokuskan sebanyak 26 responden $(40.6 \%)$
Kelelahan mata merupakan gejala yang di akibatkan oleh upaya berlebih dari sistem penglihatan yang berada dalam kondisi yang kurang sempurna untuk memperoleh ketajaman penglihatan. Timbulnya kelelahan mata dipengaruhi oleh beberapa faktor, faktor pekerjaan dan faktor lingkungan. Faktor pekerjaan dapat berupa kelainan refraksi, usia, perilaku yang beresiko, faktor keturunan dan faktor pekerja. Sedangkan faktor lingkungan yang mempengaruhi adalah intensitas pencahayaan, kualitas iluminasi, atau ukuran objek (Affandi, 2005).

Hasil penelitian ini memiliki kesamaan dengan penelitian yang dilakukan oleh Febrian Supriati mengenai faktor-faktor yang berkaitan dengan kelelahan mata pada tahun 2012. Rata-rata intensitas pencahayaan ruangan masih dibawah standar yang telah di tetapkan. Kondisi pencahayaan yang redup maupun yang menimbulkan silau akan dapat menyebabkan terjadinya keluhan seperti mata terasa berat (mengantuk) sebagai gejala umum adanya kelelahan mata, sedangkan keluhan terasa tegang pada bagian leher dan bahu merupakan dampak akomodasi mata yang berlebihan untuk menyesuaikan dengan kondisi pencahayaan yang ada. 


\section{SIMPULAN}

1. intensitas pencahayaan ruang kelas $I$ menggunakan penerangan (lampu) sebesar 27.99842 lux dan tanpa penerangan sebesar 20.27087 lux. Intensitas pencahayaan ruang kelas $\mathrm{V}$ menggunakan penerangan (lampu) sebesar 74.34536 lux dan tanpa penerangan sebesar 65.00034 lux, hasil dari perhitungan menunjukan intensitas pencahayaan ruang kelas $\mathrm{I}$ dan $\mathrm{V}$ di SDN Pagadean Subang tidak sesuai dengan standar yang telah di tetapkan dalam SNI 03-6197-2000 tahun 2011. Standar intensitas pencahayaan ruang kelas sebesar 300 lux. Hasil perhitungan, ruang kelas 1 membutuhkan kapasitas lampu sebesar 218 Watt dengan lampu sebanyak 3 titik didalam ruangan, dan ruang kelas $\mathrm{V}$ membutuhkan kapasitas lampu sebesar 136 Watt yang menjadi 140 watt dengan lampu sebanyak 2 titik didalam ruangan, tetapi untuk perhitungan jarak antar lampu tidak di perhitungkan.

2. Kejadian kelelahan mata pada siswa di SDN Pagadean Subang tahun 2017 dari 64 responden, hanya 9 siswa $(14.1 \%)$ yang dapat dinyatakan mengalami kelelahan mata dengan keluhan tertinggi yaitu mata terasa berat atau mengantuk sebanyak 34 responden $(53.1 \%)$.

\section{SARAN}

Penyelenggara pendidikan diharapkan untuk menambah intensitas pencahayaan berupa penambahan cahaya buatan yaitu lampu dengan kapasitas 140 watt dengan lampu sebanyak 3 titik didalam ruangan, dan ruang kelas $\mathrm{V}$ membutuhkan kapasitas lampu sebesar 140 watt dengan lampu sebanyak 2 titik didalam ruangan dan penambahan jendela sebagai jalan masuknya pencahayaan alami (matahari).

\section{PUSTAKA}

Affandi, Edi.S. 2005. Sindrom Penglihatan Komputer (Computer Vision Syndrome). Majalah Kedokteran Indonesia, Volume: 55, Nomor: 3.

Arikunto, S. 2013. Prosedur Penelitian Suatu Pendekatan Praktik. Jakarta: Rineka Cipta.

Budiman \& Indriani. 2012. Desain Pencahayaan Pada Ruang Kelas SMA Negeri 9 Surabaya. Dalam Jurnal Dimensi Interior, Volume: 10, Nomor: 1, ISSN: 1692-3532.

Darmasetiawan \& Puspakesuma. 1991. Teknik Pencahayaan dan Tata Letak Lampu. Jilid : Pengetahuan Dasar. Jakarta : Grasindo

Departemen Kesehatan RI. 2008. Keputusan Menteri Kesehatan Nomor 1201/MENKES/SK/VIII/2008.

Deshelia \& Ani. 2017. Evaluasi Intensitas Pencahayaan Pada Perpustakaan Di lingkungan Universitas Sriwijaya. Dalam Journal Of Industrial Hygiene And Occupational Health, Volume: 2, Nomor: 1. ISSN 
Firmansyah. 2010. Pengaruh Intensitas Penerangan Terhadap Kelelahan Mata Pada Tenaga Kerja.

Gabriel J.F. 2001. Fisika Lingkungan, Jakarta: Hipokrates.

Guyton, AC. 1991. Fisiologi Kedokteran II. Diterjemahkan oleh Adji Dharma. Jakarta : EGC Buku Kedokteran

Ilyas S. 2008. Penuntun Ilmu Penyakit Mata. Jakarta: Fakultas Kedokteran Universitas Indonesia.

Keputusan Menteri Kesehatan Nomor.1405 Tahun 2002.

Manurung. 2009. Desain Pencahayaan Arsitektural. Yogyakarta. C.V : Andi.

Mardiana. 2015. Unnes Journal Of Public Health.

Nurhani. 2011. Optimasi Sistem Pencahayaan Dengan Memanfaatkan Cahaya Alami. Dalam Jurnal Ilmiah Foristek, Volume: 1, Nomor: 1.

Notoatmodjo, S. 2012. Metode Penelitian Keehatan. Jakarta: Rineka Cipta.

Nurmianto, Dalam Jurnal Libria. 2016. Pengukuran Intensitas Penerangan. Jakarta: Prenada Media.

Pearce, EC. 2009. Anatomi Dan Fisiologi Untuk Paramedis. Alih Bahasa: Handoyono SM. Jakarta: PT Gramedia: 314-324.

Peraturan Menteri Pendidikan Nasional Nomor.24 Tahun 2007. Standar Sarana Dan Prasarana Untuk Sekolah Dasar/Madrasah Ibtidaiyah (SD/MI), Sekolah Menengah Pertama/Madrasah Tsanawiyah (SMP/MTs), Dan Sekolah Menengah Atas/Madrah Aliyah (SMA/MA).

Prabu. 2009. Sistem Dan Standar Pencahayaan Ruang.

Purnama, ED. 2017. Optimasi Desain Pencahayaan Ruang Kelas SMA Santa Maria, Surabaya. Dalam Jurnal Dimensi Interior, Volume: 9, Nomor: 2.

Semuel, JK. 2015. Desain Instalasi Penerangan Pada Bangunan Multi Fungsi. Dalam E-Journal Teknik Elektro, ISSN : 2301-8402.
Soewarno. 1992. Penerangan Tempat Kerja. Jakarta: Pusat Pelayanan Ergonomi.

Subrianto. 2011. Mengoptimalkan Pencahayaan Dan Sirkulasi Udara Untuk Menambah Kenyamanan Dan Kesegaran Rumah Tinggal. Dalam Jurnal Sipil, Volume: 5, Nomor 2.

Sugiyono. 2013. Statistik Untuk Penelitian. Bandung: Alfabeta.

Undang-Undang Republik Indonesia No 2 Tahun 1989. Sistem Pendidikan Nasional Pasal 1 ayat 1 